\title{
BAHAN DAN CARA PEMBUATAN ARCA BATU SEBAGAI KOMPONEN PENTING CANDI-CANDI MASA KLASIK DI JAWA
}

\section{MATERIAL AND METHOD OF MAKING STONE STATUE AS A KEY COMPONENT CLASSICAL TEMPLE IN JAVA}

\author{
T.M. Hari Lelono \\ Balai Arkeologi Yogyakarta \\ harilono@gmail.com
}

\begin{abstract}
Most of the building of temples Hindu / Buddhist in Java, always equipped with statues as a symbol of the manifestation of the gods. These statues are usually placed in the temple chambers in accordance with their respective functions. One thing that is interesting about how to obtain the materials and manufacturing process performed by the artists sculpture carving during the Ancient Java era?. Therefore, the approach tries to uncover ethno-archaeology through ethnographic data. From these data, expected to be useful for science as well as add insight for anyone who wants to know about the 'secret' making of the statues in the Java-Kuna. Our ancestors have proven that they have the genius of local identity and identity as a cultural and civilized nation.
\end{abstract}

Keywords : Material statue, Sculpture Artist, Classical Temples Period.

\begin{abstract}
ABSTRAK
Sebagian besar bangunan candi-candi Hindu/ Budha di Jawa, selalu dilengkapi dengan arca-arca sebagai simbol dari perwujudan para dewa-dewa. Arca-arca tersebut biasanya diletakkan pada bilik-bilik candi sesuai dengan fungsinya masing-masing. Suatu hal yang menarik tentang bagaimana caranya memperoleh bahan dan proses pembuatan arca dilakukan oleh para seniman pahat pada maa Jawa-Kuna ?. Oleh karena itu, dengan pendekatan etnoarkeologi akan mencoba mengungkap melalui data etnografis. Dari data tersebut, diharapkan dapat bermanfaat bagi ilmu pengetahuan serta menambah wawasan bagi siapa saja yang ingin mengetahui tentang 'rahasia' pembuatan arca-arca pada masa Jawa-Kuna. Nenek moyang telah membuktikan, bahwa mereka memiliki lokal genius dan jatidiri sebagai identitas Bangsa yang berbudaya dan beradab.
\end{abstract}

Kata kunci: Bahan Arca, Seniman Pahat, Candi-Candi Masa Klasik. 


\section{PENDAHULUAN}

Arkeologi Indonesia kini telah memasuki babakan baru yakni mulai dikenal dan disukai oleh beberapa lapisa masyarakat tertentu. Walaupun umurnya relatif tua, sejak dirintis oleh Pemerintah Hindia Belanda. Arkeologi Indonesia dibentuk pada masa pemerintahan Hindia Belanda, tanggal 14 Juni 1913 dengan nama Oudheidkundige Dienst in Nederlansch-indie. Lembaga ini pada mulanya menangani urusan dalam konteks kesenian, etnografi, arsitektur, dan filologi. Tetapi dalam usianya yang ke 100 ? telah menjadi sebuah lembaga yang secara khusus menangani 'dunia' arkeologi Indonesia, dan pada pasca kemerdekaan Republik Indonesia telah dikembangkan ke dalam beberapa bidang studi menjadi arkeologi prasejarah, arkeologi klasik (Hindu \& Budha), dan arkeologi Islam/ kolonial.

Dari serangkain studi dan konservasi arkeologis yang telah dilakukan, salah satunya adalah peninggalan-peninggalan masa klasik yaitu masa pengaruh kebudayaan Hindu dan Budha sekitar abad V M - XV M. Pada masa berkembangnya budaya tersebut, telah meninggalkan bangunan monumental salah satunya adalah candi-candi yang berfungsi sebagai tempat pemujaan atau pendharmaan bagi seorang raja yang telah meninggal dunia. Sebagai tempat yang disucikan pada masa lalu, telah menjadi tradsisi turun-temurun oleh beberapa masyarakat yang hidup di sekitar candi untuk melakukan ritual kepercayaan maupun keagamaan. Sebagai tempat suci candi biasanya dilengkapi dengan arca-arca para dewa, sebagai sentrum/ pusat pemujaan. Oleh karena itu, arca yang merupakan simbolisasi perwujudan para dewa-dewa tersebut, dibuat oleh seniman pahat dengan sebaik-baiknya mengacu pada kaidah yang ditentukan dalam Agama Hindu-Budha, seperti misalnya atribut yang melengkapi arca, asesoris dan ukuran besar kecilnya sebuah arca.

Sebuah desa, dahulu dikenal dengan nama Desa Prumpung, kini telah berubah namanya menjadi Desa
Sidoarjo. Terletak dalam wilayah Kelurahan Taman Agung, Kecamatan Muntilan, Kabupaten Magelang, Propvinsi Jawa Tengah. Prumpung, merupakan sebuah desa kerajinan pahat batu dengan membuat arca-arca dan peralatan dapur. Lokasi desa ini cukup strategis, yaitu terletak ditengah-tengah antara Gunung Merapi dengan Candi Borobudur berjarak sekitar 22 kilometer. Lereng Merapi, Desa Sidoarjo (Prumpung) dan Candi Borobudur, pada abad IX M terbentuk jalinan sakral yang lahir lewat penghayatan masyarakatnya dalam pembangunan tempat ibadah yang berdiri kokoh dan megah. Diawali oleh gagasan besar Wangsa Syailendra untuk membangun tempat ibadah bagi warganya (Hernaningsih 1990, 2)

Selama ini, pengunjung situs-situs cagar budaya, khususnya yang berupa candi jarang berfikir atau mengetahui, tentang bahan dan sumber batuan yang digunakan untuk membangun candi, apalagi tentang bahan dan cata membuat arca yang merupakan unsur penting dalam candi tersebut ?. Hal itu menjadi sangat menarik untuk ditulis, sebagai pengetahuan bagi masyarakat tentang olah, kreatifitas para seniman pahat pada masa Jawa Kuna. Guna menjawab pertanyaan tersebut, maka dengan melakukan studi etnoarkeologi untuk merekam data etnografis yang masih bisa ditemukan pada beberapa masyarakat, khususnya seniman pahat arca. Seperti telah diketahui, bahwa pembuatan arca tidak bisa dilakukan oleh sembarang orang dan harus dilakukan oleh seorang seniman pahat. Seorang seniman yang ditugasi untuk membuat arca dewa harus mengikuti ketentuan-ketentuan yang berlaku dan termuat dalam çilpaçastra, sebuah kitab di India yang berisi ketentuan-ketentuan dalam pembuatan arca. Dalam kitab tersebut terdapat ketentuan-ketentuan yang harus diikuti, misalkan membuat arca dewa-dewa pada level utama, ukurannya berbeda dengan dewa-dewa dengan level di bawahnya. Hal tersebut, berkaitan dengan filosofi Hindu dewadewa memiliki strata tertentu, misalkan Dewa Brahma, Wisnu Siwa merupakan Dewa dalam level pertama, sedangkan 
Dewi Sri, Tara pada level yang kedua (di bawahnya). Dalam konteks tersebut, seorang pemahat harus tahu ukuranukuran serta tujuan membuat arca, apakah akan digunakan sebagai benda sakral (suci) atau hanya sebagai benda profan. Sebagai benda yang berfungsi sakral tentu akan dikerjakan dengan mengacu aturan, pertimbangan dan bahan yang terpilih.

Arca dewa merupakan salah satu komponen penting dalam sebuah bangunan suci yang bermanfaat sebagai media untuk membantu melakukan konsentrasi pemujaan bagi umatnya. Sebagai sebuah benda yang disakralkan tentu memiliki persyaratan khusus dalam pembuatnnya, yaitu bahan, ikonografi (sikap dan asesoris sebagai pertanda atau identitas tokoh), ikonometri (ukuran besar atau kecil dan perbandingan sebuah arca yang membedakan antara dewa-dewa utama dan dewa-dewa di bawahnya), serta seniman pemahatnya. Ke-empat syarat tersebut seluruhnya saling berkaitan, sehingga dapat menghasilkan sebuah karya yang sempurna. Mulai dari pemilihan bahan yang tidak boleh cacat (warna belang, harus utuh), peralatan yang digunakan, perlengkapan asesoris sebagai ciri-ciri tokoh tertentu, ukuran-ukuran arca yang telah ditentukan, serta perilaku para pemahat yang kadang harus melakukan ritual, untuk memohon pada 'Sang Penguasa' agar hasil karyanya dapat diselesaikan dengan baik.

Berdasarkan data etnografis dan wawancara yang dilakukan terhadap para seniman pahat, bahwa membuat arca dewa yang berkaitan dengan sakral, terdapat ketentuan-ketentuan khusus. Sebagai seorang pemahat, hal-hal teknis tentang ukuran, bentuk dan asesoris arca tidak ada kendala. Hal penting yang harus diperhatikan, adalah pada persiapan dan perilaku pemahat dengan melakukan suatu kegiatan berkaitan degan keyakinan, ritual tertentu yang diajarkan secara turun temurun kepada generasi penerusnya. Perilaku ritual menjadi salah satu syarat utama, supaya tokoh atau arca dewa tertentu yang dikerjakan bisa kelihatan, anggun, hidup dan berwibawa. Hal tersebut menjadi penting, karena terjadi semacam 'kontak' batin atau hubungan emosional antara arca dewa yang dikerjakan dengan pemahatnya. Sehingga hasil karya tersebut akan tampak memiliki 'roh' yang hidup.

Perilaku ritual tersebut, kiranya dapat dijadikan sebagai sebuah analogi, bahwa arca/ arca-arca dewa dalam sebuah candi kelihatan indah, bagus, anggun dan terkesan 'hidup' berkat adanya hubungan tarik-menarik atau hubungan emosional antara arca/ tokoh dengan pembuatnya. Memang, aktivitas dan perilaku ritual para pemahat sebagai langkah awal, karena arca yang ditempatkan dalam bangunan-bangunan suci (candi dan lain-lain), sebelum dimanfaatkan sebagai media pemujaan, dilakukan peresmian dengan berbagai upacara yang biasanya dipimpin oleh seorang atau lebih pendeta untuk 'menghidupkan' tokoh/ dewa-dewa tersebut, sehingga menjadi suci/ sakral.

Data etnografis telah membuka cakrawala tentang aktivitas dan perilaku utamanya berkaitan dengan hal-hal yang bersifat ritual/ sebagai budaya intangible. Masyarakat sekarang dari sisi keyakinan agama telah mengalami perubahanperubahan, tetapi dalam hal kepercayaan dan tradisi secara naluriah masih ada yang melakukan tradisi dan kebiasaan nenek moyangnya. Hal tersebut karena berkaitan dengan halhal yang dipandang bernilai positif, sehingga masih dipertahankan dan merupakan benteng atau pertahanan budaya dari pengaruh asing. Oleh karena itu, dapat juga dikemukakan, kebudayaan adalah keseluruhan proses dan hasil perkembangan manusia yang disalurkan dari generasi ke generasi untuk kehidupan manusiawi yang lebih baik. Hal tersebut semakin memperkokoh jatidiri dan identitas Bangsa Indonesia, khususnya Jawa, bahwa kepandaian membuat arca-arca para dewa merupakan hasil karya tangan nenek moyang, berdasarkan nilai-nilai lokal yang adiluhung.

Oleh karena itu, mengacu pada peran pentingnya sebuah arca pada bangunan candi menimbulkan permasalahan yang menarik, adalah 
bagaimana cara pembuatan arca, peralatan yang digunakan, bahan yang digunakan, serta siapa pembuatnya? Hal tersebut, sangat menarik untuk dijawab guna menambah ilmu pengetahuan bagi masyarakat luas, serta menambah pengetahuan bagi pengunjung candicandi dimanapun berada. Pengetahuan tersebut, diaharapkan dapat menambah cakrawala dan wawasan berfikir masyarakat, serta menambah keyakinan tentang nilai-nilai jatidiri Bangsa Indonesia, bahwa nenek moyang telah mengenal teknologi dan kearifan lokal yang patut dibanggakan.

\section{METODE PENELITIAN}

Arca dewa-dewa yang mengisi dalam bangunan candicandi, dibuat oleh para seniman pahat pada masa Jawa Kuna, pada sat ini proses pembuatan tersebut tidak dapat dilihat, karena terjadi pada sekitar seribu tahun lalu. Selain itu, masih banyak hal-hal yang tidak dapat diketahui, seperti perilaku pemahatnya, jenis-jenis peralatan secara kualitas dan kuantitasnya yang digunakan untuk memahat. Bahan batu dperoleh dari mana, jenis bahan, cara pemilihan batu yang bagus dan cara pengangkutan bahan dari tambang ke lokasi pemahatan. Hal tersebut dilakukan supaya menghasilkan arca yang berkualitas baik. Oleh karena itu, untuk mengetahuinya perlu dilakukan dengan menggunakan data pembanding yaitu para seniman pahat batu yang masih dapat kita temukan di beberapa daerah di sekitar Magelang, salah satunya ada di Desa Prumpung, Kecamatan Muntilan, Magelang Jawa Tengah.

Dalam upaya untuk memperoleh data-data, sebagai data untuk pembanding/analogi tersebut, digunakan pendekatan etnoarkeologi. Dalam hal ini terdapat dua model pendekatan, yaitu pendekatan kesinambungan sejarah (direct historical) dan perbandingan umum (general comparative). Pendekatan pertama didasarkan pada pandangan bahwa kebudayaan yang berkembang sekarang ini merupakan kelanjutan dari kebudayaan masa lalu. Oleh karena itu, studi etnoarkeologi akan relevan dilakukan jika antara data etnografi dan data arkeologi memiliki persamaan atau kesinambungan sejarah. Pendekatan kedua yaitu perbandingan umum didasari oleh pandangan bahwa hubungan antara budaya arkeologi yang pendukungnya telah punah dengan budaya yang masih berlangsung, pada hakekatnya adalah hubungan bentuk, sehingga tidak perlu memiliki kaitan historis, ruang, dan waktu. Namun demikian, pendekatan ini menuntut persyaratan yaitu perlu adanya kesamaan dalam bentuk budaya maupun lingkungan antara data etnografis dengan data arkeologis (Watson, 1971: 50). Pemanfaatan analogi etnografis untuk membantu menjelaskan data arkeologi, secara lebih rinci terdapat enam syarat yang perlu diperhatikan: 1) semakin dekat jarak waktu antara data etnografi dengan data arkeologi, semakin baik hasilnya, 2) adanya kesamaan satuan tingkat kelompok masyarakat yang dibandingkan, 3) adanya tingkat yang sama dalam mata pencaharian, 4) berada pada wilayah yang berdekatan, 5) adanya kencenderungan linguistik yang sama, dan 6) terjaganya konservativitas budaya etnografis (Hole dan Heiser 1973, 312). Pada syarat 1) benda etnografi yang serupa dengan candi dan dikeramatkan oleh penduduk sudah tidak ada, tetapi mereka membuatnya dengan melakukan persyaratan berkaitan dengan hal-hal yang religius/sakral; Pada syarat yang ke 2), 3), 4) dan 5) pada umumnya termasuk kelompok yang secara umum bercirikan dan bermata pencaharian di sektor pertanian (agraris). Sedangkan lokasi dengan candi-candi tidak terlalu jauh antara tiga (3) sampai dengan 10 kilometer begitupula dalam linguis yang digunakan adalah bahasa Jawa, tetapi tentunya sudah mengalami banyak perubahan pengucapan, konsunan, maupun artinya, tetapi masih menggunakan bahasa ibu yang sama, kalau dulu bahasa Jawa kuna sekarang menjadi bahasa Jawa baru. Dalam syarat no 6), konservasitivitas budaya materi yang (tangible) sudah kurang nyata, tetapi dalam adat dan tradisi atau 
budaya nom-materi (intangible) masih menunjukkan konservasi dan pelestariannya, karena mereka masih melakukan upacara ritual berkaiatan dengan oleh agraris (menanam padi, wiwitan), maupun dalam membuat arcaarca, yaitu sebelum melakukan aktivitas tersebut mereka selalu melakukan upacara.

Seniman pahat Prumpung, secara langsung tidak ada kaitannya dengan para seniman pembuat arca pada candicandi di sekitarnya, karena tempat tinggal desa pembuat arca pada masa itu belum ditemukan. Desa Prumpung, yang mendalam tentang aktivitas pembuatan arca-arca. Sehingga dapat diperoleh gambaran secara holistik, tentang proses pembuatan arca pada masa kini, sebagai analogi pada masa Jawa Kuna.

\section{SUMBER BAHAN DAN PEMBUATAN ARCA}

\section{Sumber Bahan}

Pada umumnya jenis batuan andesit sama jenisnya, begitupula yang digunakan bahan untuk membangun candi-candi diambil langsung dari hasil

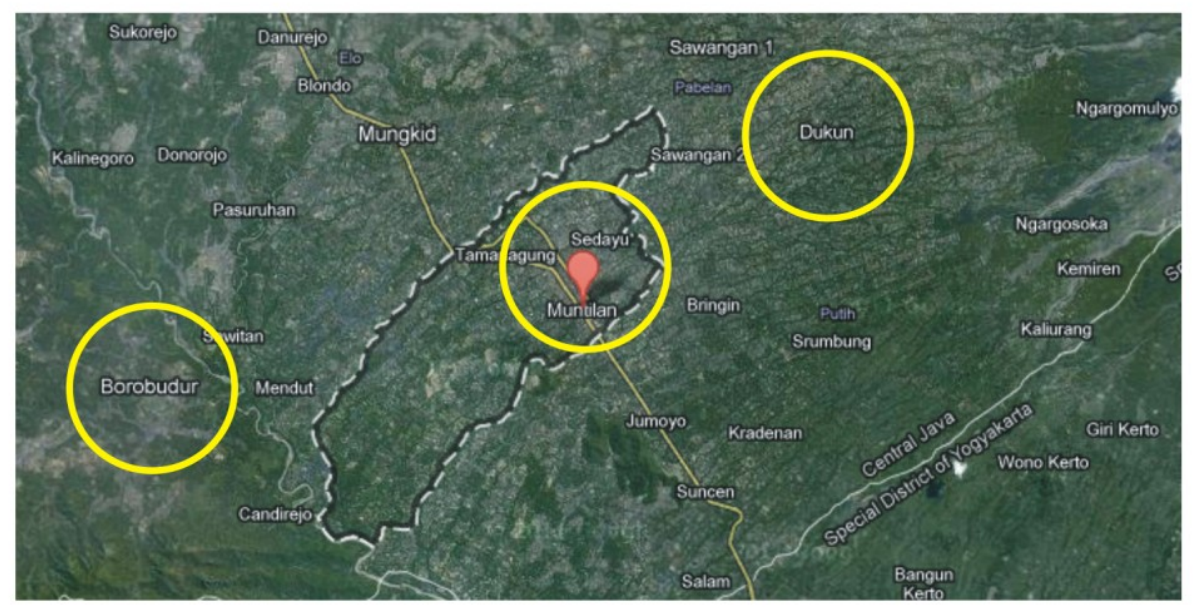

Peta 1. Keterangan Lokasi: Tengah Desa Prumpung, kanan Desa Dukun tempat penambangan batu. Kiri Candi Borobudur

Sumber: imagery (C2013.terrametrics. google.map.it

dikenal sebagai salah satu desa kerajinan pahat batu yang membuat arca, batu nisan (kijing), dan peralatan untuk rumah tangga seperti cobek/ cowek. Desa tersebut letaknya 11 kilometer di sebelah timur Candi Borobudur, di sekitarnya juga banyak ditemuan candi-candi yang yang cukup dikenal oleh masyarakat, seperti Candi Asu, Candi Gunung Kelir dan candicandi kecil lainnya yangh ditemukan dalam kondisi tinggal struktur bagian kaki candi. Oleh karena itu, dalam mengumpulkan informasi dan data dan melihat langsung aktivitas seniman pahat batu, dilakukan wawancara mendalam (depth interview), dan dilekukan dengan cara cara sampling. Seluruh data yang berhasil dihimpun akan dianalisis secara kualitatif, agar memperoleh gambaran tambang di dalam tanah atau tebingtebing jurang, dan bukan diambil langsung dari batuan andesit yang banyak terdapat di sungai-sungai yang berhulu di Gunung Merapi. Bahan batu andesit tersebut diperoleh dari daerah lain dengan jarak sekitar 10 kilometer, ke arah Gunung Merapi, termasuk dalam wilayah Kecamatan Dukun. Di kecamatan ini banyak desa-desa, seperti Desa Mirondo, Glendeng, dan Dukun yang melakukan penambangan pasir dan batu hasil erupsi gunung berapi. (unduh internet daerah tersebut)

Penambangan batu dimulai sejak sekitar tahun 1960 sampai sekarang, pada awalnya dilakukan secara manual, tetapi kini banyak dilakukan dengan menggunakan alat ekskavator. Batu-batu ditemukan di kedalaman antara $3-5$ 
meter tersebut terdiri dari bermacam ukuran dan jenis batu, batu andesit berkualitas baik digunakan sebagai bahan arca, sedangkan batu yang keras digunakan sebagai bahan bangunan. Di ke dalaman tersebut, banyak ditemukan batu berkualitas baik berwarna abu-abu tua dengan porositas rapat, sehingga tidak mudah pecah ketika sedang dikerjakan.

Pada waktu lalu bahan batu dapat diperoleh di atas permukaan tanah, walaupun kualitasnya kurang baik, tetapi saat ini harus ditambang dengan cara menggali tanah. Tanah diperoleh dengan cara menyewa/ beli untuk mengambil pasir dan batunya saja, setelah lahan habis dikerjakan seluruhnya, maka tanah akan dikembalikan kepada pemiliknya. Harga sewa tanah tersebut cukup mahal dapat mencapai jutaan rupiah, tergantung pada luas dan dugaan kandungan material yang terdapat di dalamnya. Salah satu cara untuk mengetahui kandungan batu di dalam tanah adalah dengan menusuknusukkan linggis ke dalam permukaan tanah. Jika ujungnya terantuk benda keras/ batu akan terasa dan tindakan tersebut dilakukan terus-menerus disekelilingnya untuk mendeteksi sebaran dan besaran batunya. Bagi penambang yang berpengalaman dapat memprediksi ukuran besar atau kecilnya sebuah gundukan batu, hal itulah yang akan menjadi pertimbangan penyewa untuk proses tawar-menawar dengan pemilik lahan.

Proses mencari batuan tersebut, dimulai dengan mengangkat pasir atau tanah yang ada di permukaan, dan setelah mencapai kedalaman tertentu baru ditemukan batuan andesit dalam ukuran tertentu. Untuk membelah batubatu di dalam tanah dijadikan bentuk balok-balok batu tersebut digunakan alat yang dinamai belah dibuat dari bahan besi tempa berukuran panjang antara 10 $\mathrm{cm}$ sampai $15 \mathrm{~cm}$ dengan lebar ujung yang tajam $2 \mathrm{~cm}$, sedangkan bagian ujung lainnya $3 \mathrm{~cm}$ sebagai bidang pukul. Palu, digunakan untuk memukul berukuran panjang sekitar $90 \mathrm{~cm}$ dengan berat mencapai 5 kilogram. Sebelum dipotong/ belah dbuatlah garis-garis lurus menggunakan kapur atau digaris dengan alat belah. Garis-garis lurus kemudian setiap $20 \mathrm{~cm}$ dipancangkan belah mengikuti garis yang ada, kemudian dipukul secara perlahan-lahan bergantian dan merata pada permukaan batu tersebut, pada akhirnya batu akan terbelah dengan sendirinya. Balokanbalokan batu setelah digeser dari tempat semula, kemudian dipotong-potong menjadi balokan-balokan batu dengan ukuran lebih kecil, sesuai dengan permintaan atau pesanan para pemahat.

Balokan batu yang dihasilkan kemudian dilakukan pemilahan, karena sekurangnya bisa ditemukan dua jenis,

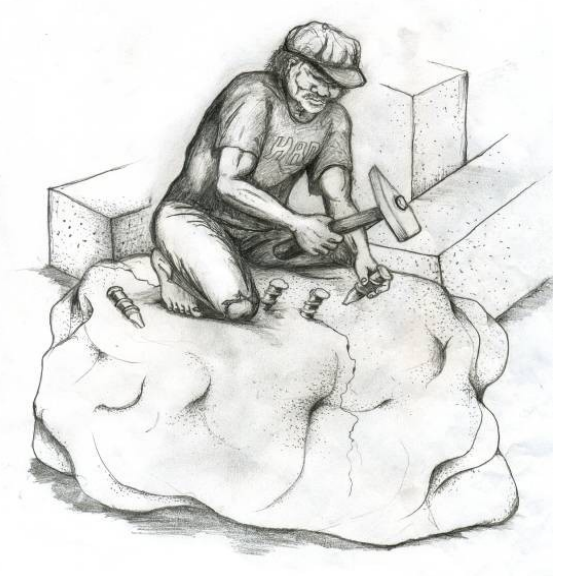

Gambar 1. Membelah batu untuk dijadikan balokan-balokan bahan patung

Gambar: Hadi Sunaryo Balar Yogyakarta

berwarna abu-abu tua dan merah keputihan dengan kualitas yang berbeda, batu berwarna abu-abu tua dengan kristal kecil-kecil berukuran kurang lebih 1 mili meter dan porositasnya padat sangat baik untuk arca. Sedangkan batu yang berwarna merah keputih-putihan kristalnya agak renggang cenderung lebih lunak/ rapuh, sehingga mudah pecah dan ditumbuhi lumut. Menurut Doekamid seorang seniman arca senior di Prumpung, berdasarkan pada pengalamannya, bahwa; “...batu yang didapat di dalam tanah lebih baik, karena pori-porinya padat dan berumur relatif lebih tua..." Hal tersebut, berkaitan dengan proses pemahatan arca, keras atau lunaknya batu yang ditatah sesuai 
dengan keinginan pemahatnya. Khususnya untuk bahan membuat arca, terdapat perbedaan dalam hal porositas batu dan warna abu-abu tua, jenis tersebut yang berkualitas baik. Batuan jenis tersebut banyak didapatkan di daerah pegunungan sebagai akibat dari erupsi dan pengendapan lahar/ magma gunung api. Batuan andesit yang berasal dari letusan gunung api (lahar) ini berawarna abu-abu, berbutir halus, sering berongga dan terdiri dari mineral plaglioklas, ampibol dan pyroxen. Pelapukan berwarna coklat atau merah coklat (Ensiklopedia Indonesia 1980, 211).

Ukuran balok batu besar yang selama ini pernah dipesan dapat mencapai ukuran $1.5 \mathrm{~m} \times 4 \mathrm{~m}$ dengan berat mencapai sekitar tujuh (7) ton. Mahalnya batu berukuran besar, selain susah untuk mendapatkannya juga disebabkan perlu hati-hati dalam pengangkatan dan pengangkutan menggunakan alat transportasi dengan jarak sekitar 10 kilometer dan kondisi jalan yang berlubang-lubang. Pada jaman dahulu, alat transportasi yang digunakan menggunakan gerobag dengan ditarik oleh dua ekor sapi, balokan batu yang diangkut berukuran tidak terlelu besar, karena faktor kemanan dan daya muat gerobag yang terbatas. Gerobag merupakan alat transportasi tradisional yang sangat fleksibel untuk mengangkut hasil pertanian dan benda atau barang-barang dalam jumlah yang cukup banyak dan mampu melakukan perjalanan jauh, sampai pelosok pedesaan. Namun sesuai dengan perkembangan alat transportasi moderen, saat ini penggunaan kendaraan truk dapat mengangkut beban lebih banyak dengan ukuran yang lebih besar.

Balokan batu setelah sampai di tempat para pemahat, kemudian akan dipilah lagi berdasarkan pada jenis warna dan porositasnya. Batu yang kualitas baik akan digunakan untuk membuat arca, sedangkan yang kurang baik digunakan untuk membuat alat-alat rumah tangga atau arca dan hiasanhiasan kontemporer. Secara empirik para seniman pahat tersebut untuk membuat arca diperlukan beberapa syarat, antara lain: Pertama, batu harus utuh tidak ditemukan retakan, tidak berongga dan tidak berserat kasar; Kedua, permukaan batu harus satu warna tanpa ada bercak-bercak dengan warna yang berbeda; Ketiga, batu harus berukuran relatif besar, untuk membuat arca dengan ukuran yang diinginkan oleh pemesan. Setelah persyaratan secara fisik dipenuhi, barulah mereka mengerjakan arca.

\section{Jenis-Jenis Peralatan Pahat}

Membuat arca batu diperlukan keterampilan secara khusus dan harus memiliki jiwa seni, karena kedua hal tersebut akan menentukan kualitas hasil karya tersebut. Selain kedua hal tersebut, tentu harus didukung pula oleh material bahan dan alat bantu untuk mengerjakan, yaitu seperangkat peralatan yang dibuat khusus berupa alat-alat pahat bermacam ukuran dan jenisnya, meteren dan palu (hammer). Pada masa Jawa Kuna, telah dikenal pande=pande besi yang khusus mengerjakan alat-alat dari bahan besi yang ditempa sehingga berkualitas, tajam dan awet. (cari literatur pande besi). Alat-alat tersebut pada awalnya dipesan pada pande-pande besi yang ada disekitarnya, agar proses dan bahan besi/ baja menggunakan bahan yang berkualitas. Selain itu setiap pemahat diwajibkan bisa menempa alat-alat yang akan digunakan. Hal tersebut, dilakukan karena semua alat sebelum dan sesudah digunaka harus dalam kondisi yang tajam dengan cara penyepuhan, supaya dapat terjaga ketajaman dan kekuatan bajanya. Oleh karena itu setiap bengkel kerja arca pasti memiliki alat untuk menempa/ memanaskan alat-alat yang akan atau sesudah digunakan berupa ububan. 
Alat memahat yang dibuat dari bahan baja dan besi yang ditempa memiliki kualitas kekerasan logam dan ketajaman yang baik, sehingga mudah untuk mengerjakan bahan batu sesuai dengan kemauan pemahatnya. Ada bermacam jenis dan alat, dalam hal ini
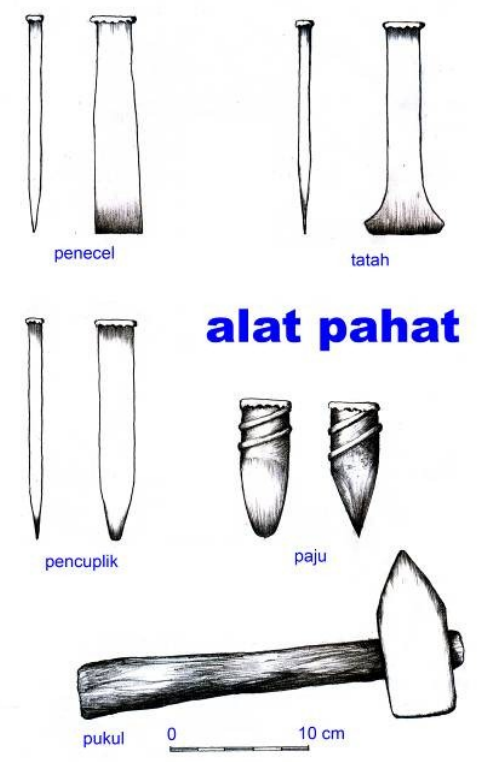

Gambar 2. Alat-alat pahat

Gambar: Hadi Sunaryo Balar Yogyakarta

akan diberikan contoh alat-alat utama yang digunakan oleh pemahat. Alat-alat tersebut terdiri dari jenis, fungsi dan ukaran besar/ kecilnya sebuah alat yang disesuaikan dengan arca yang dibuatnya, antara lain:

a. Cuplik: berukuran panjang $20 \mathrm{~cm}$ diameter $1 \mathrm{~cm}$ dan runcingan sekitar $0.5 \mathrm{~cm}$, bentuk bulat lonjong, mata pahat bentuknya agak runcing. Berfungsi untuk mengkikis bongkahan batu pada tahap awal pemahatan.

b. Penyecel: berukuran panjang 20-25 $\mathrm{cm} \times 2.5 \mathrm{~cm}$ dengan lebar mata pahat antara $1-2 \mathrm{~cm}$, bentuk pipih memanjang. Berfungsi untuk menyelesaikan detail detail arca dan untuk membuat lubang-lubang pada bagian tertentu arca.

c. Tatah: berukuran panjang $20 \mathrm{~cm}$ dengan lebar permukaan pahat bervariasi antara $3-6 \mathrm{~cm}$ tangkainya $2 \mathrm{~cm}$. Alat ini berfungsi untuk meratakan permukaan bentuk global arca.

d. Belah/ paju: Bentuk pipih panjang 15 $\mathrm{cm} X$ lebar mata pahat $2 \mathrm{~cm}$, digunakan untuk membelah atau memotong-motong bongkahan batu yang besar.

e. Palu: mata palu dari bahan besi dengan bentuk persegi panjang, berat antara $0.5-2 \mathrm{~kg}$ menggunakan tangkai kayu dengan panjang $25 \mathrm{~cm}$. Digunakan untuk memukul pahat.

Setiap kali menggunakan alat pahat/ tatah, akan mengalami keausan sehingga kurang tajam yang dapat menyebabkan arca mudah patah. Oleh karena itu, pemahat harus selau mengasah dan mengeraskan kembali baja/ alat yang digunakan dengan cara (penyepuhan). Peralatan yang diperlukan, di antaranya: Anglo (bahan dari tanah liat) untuk pembakaran menggunakan bahan dari arang, air dalam ember, tanah basah/ lumpur, dan penjepit dari bambu. Proses penyepuhan dilakukan setelah alat-alat ditempa lebih dahulu, sehingga dalam kondisi tajam. Alat yang sudah tajam tersebut kemudian di panasi dalam bara api (sepuh) sampai berwarna merah. Kemudian diangkat denga penjepit bambu bambu, lalu dicelupkan ke dalam air selama kurang lebih 2 detik, diangkat sampai permukaan logam berubah warna dan dicelup lagi ke air selama 1 detik, kemudian diangkat dan dimasukkan ke dalam tanah/ lumpur basah selama 20 menit. Setelah 20 menit tatah tersebut segera diangkat, karena jika lebih alat tersebut besinya akan kembali menjadi muda dan proses penyepuhan harus diulangi lagi. Alat-alat tersebut didiamkan selama semalam dan dapat digunakan kembali dengan ketajaman dan kekerasan yang ideal. Proses penempaan dan penyepuhan dilakukan setiap hari setelah mereka selesai bekerja, dan seluruh alat telah siap digunakan pada esok harinya.

\section{Memilih Batu}

Memilih bahan, merupakan langkah awal yang sangat penting, apalagi arca yang akan dibuat adalah 
arca dewa dengan ukuran yang relatif besar. Semakin besar yang akan dibuat semakin sulit untuk memilih bahan yang berkualitas baik, karena memiliki beberapa syarat, antara lain: warna permukaan batu harus rata misalkan berwarna abu-abu tua, porositas batu pada seluruh permukaan harus sama, karena dapat berpengaruh dalam proses pengerjaan (tatahan), dan batu harus utuh tidak retak atau keropos. Oleh karena itu, sebelum mengerjakan arca harus ditentukan dulu batu yang akan digunakan dengan melakukan pengetesan bahan, apakah batu tersebut memiliki warna dan porositas yang sama, serta tidak ada yang retak dan keropos. Cara yang lazim dilakukan, adalah dengan memukul-mukul balokan batu dari berbagai arah secara merata pada ke-empat sisinya, menggunakan palu yang besar. Dari pukulan itu, akan menimbulkan suara, apabila bersuara nyaring pertanda batu tidak retak atau berongga di bagian dalamnya. Tetapi apabila terdengar suara yang sebaliknya (tidak nyaring) pertanda batu tersebut keropos, retak atau berongga dan sebaiknya diganti dengan bahan batu yang lain. Hal tersebut dilakukan berulang-ulang sampai benar-benar yakin bahwa batu tersebut utuh. Suatu hal yang agak sulit, adalah menentukan warna batu dan porositasnya yang sama. Dalam langkah ini dilakukan pengamatan dengan seksama di ke-empat sisi balok batu, sambil mengkorek-korek permukaan menggunakan tatah, penyecel atau bahan besi lainnya.. Dari hasil pengamatan tersebut jika tidak ditemukan tanda-tanda warna atau garisgaris warna yang berbeda, selain porositas batunya merata, Serta dibantu oleh pengalaman empirik dengan mengunakan insting/ nalurinya, maka mereka bisa merasa yakin, bahwa batu yang dipilinnya telah sesuai dengan yang diharapkan.

\section{Teknik Pembuatan Arca}

Membuat arca diperlukan daya imajinasi yang kuat yang biasa dimliki oleh setiap seniman, semuanya dilakukan untuk menghasilkan sebuah karya yang bernilai seni tinggi dan berkarakter. Dalam konteks tersebut seniman akan sangat dipengaruhi oleh motivasi yang melatari, sehingga ia melakukan pembuatan arca. Bagi para pemahat di Prumpung merupakan sebuah pekerjaan untuk mengekspresikan jiwa seni yang dimiliki dan sebagai salah satu sumber penghasilan bagi keluarganya. Oleh arena itu, dalam membuat mengerjakan pesanan akan dilakuan dengan ketelitian sehingga para pemesan merasa senang akan hasil karyanya. Sebagai pemahat ada dua jenis pekerjaan yang dikerjakan sehari-harinya, yaitu membuat arca-arca kontemporer atau kreasi baru sesuai dengan kebutuhan knsumennya, selain itu membuat arca-arca dalam bentuk manusia, tokoh, dewa-dewa tertentu dalam Agama Hindu dan Budha. Membuat arca dewa diperlukan keterampilan dan keahlian khusus, seperti tentang bentuk, sikap, asesoris arca dan ukuran yang sebenarnya ada ketentuan-ketentuan yang harus diikuti. Tidak semua pemahat mengetahui ketentuan yang disyaratkan tersebut, karena mereka mengerjakan berdasarkan contoh atau gambar yang telah dibuat oleh para seniman yang lebih senior.

Membuat arca pesanan yang akan ditempatkan pada kuil-kuil atau tempattempat suci, ada ketentuan-ketentuan yang harus dipenuhi oleh seiman pahat, karena akan menjadi arca yang sakral. $\mathrm{Di}$ depan telah disebutkan adanya ketentuan yang dimuat dalam Kitab çilpaçastra, misalkan membuat arca dewa-dewa pada level utama, ukurannya berbeda dengan dewa-dewa dengan level di bawahnya. Dalam uraian di bawah akan dijelaskan beberapa ketentuan tersebut.

Pada umumnya untuk membuat arca, seorang seniman terlebih dahulu harus melihat bentuk model yang akan ditiru melalui gambar-gambar foto, literatur, atau melihat langsung arca yang terdapat dalam bangunanbangunan/ candi tertentu. Cara tersebut dilakukan agar memperoleh gambaran tentang bentuk, jenis dan ukuran yang akan dibuat. Dalam hal ini diperlukan 
kejelian, keakuratan dan daya imajinasi yang kuat, agar arca hasil karyanya sesuai dengan contohnya. Setelah semua dicatat dengan gambar sketza dan direkam dalam pikiran/ imajinasinya, kemudian menyiapkan bahan-bahan yang diperlukan seperti batu andesit dan peralatan pahat. Dalam proses pembuatan tersebut, sekurangnya ada 5 (lima) tahap yang harus dilakukan, antara lain:

a. Pertama, membuat sket atau gambar secara kasar pada media batu di keempat sisinya dengan menggunakan kapur tulis atau arang. Coretan-coretan tersebut berfungsi sebagai pengontrol jangan sampai pemahatan di luar gambar/ jalur yang ditentukan.

b. Kedua, mulai melakukan pengkikisan permukaan batu yang masih kasar supaya lebih rata dan halus dengan cuplik bagain demi bagian yang ada di luar coretan dari segala sisi dengan tujuan untuk membuat bentuk global dengan cara dipahat sedikit demi sedikit, hingga tercapai bentuk global keseluruhan.

c. Ketiga, mengembangkan bentuk global dengan meratakan permukaan arca dan membentuk anatomi, alat yang digunakan adalah tatah berukuran besar dengan lebar mata pahat sekitar $6 \mathrm{~cm}$, sedangkan tatah kecil dengan mata pahat sekitar $3 \mathrm{~cm}$. Besar atau kecilnya tatah yang digunakan tergantung dari luas atau sempitnya bidang dan anatomi arca yang dikerjakan.

d. Keempat, membuat detail-detail arca dengan atribut-atribut yang melengkapinya, mulai dari bagian wajah sampai pada bagian kaki. Pada tahap detail ni dikerjakan dengan hati-hati, karena rumitnya bagian-bagian yang kecil, utamanya membuat bagian wajah arca. Alat yang digunakan adalah penyecel dengan berbagai ukuran yang disesuaikan dengan luas bidang yang akan ditatah, alat tersebut juga digunakan untuk membuat lubang pada arca.

e. Kelima, merupakan tahap akhir dalam proses pembuatan arca, pada tahap ini menghaluskan seluruh permukaan arca. Ada dua cara dalam menghaluskan, pertama menggunakan pecahan batu dengan menggosok-gosokkan ke permukaan arca, setelah itu baru menggunakan gerinda. Pada saat proses penggosokan arca selalu dibasahi dengan air, untuk mengetahui halus tidaknya arca dan mengurangi tebaran debu. Pada tahap ini perlu kehati-hatian, kerena detail berupa bagian wajah dan atribut-atribut perlengkapan sebuah arca harus dengan teliti, karena mudah patah dan retak. 
Seorang pemahat, dalam mengerjakan sebuah arca harus mengetahui dengan pasti anatomi arca yang akan dibuatnya, karena tiap-tiap tokoh memiliki ukuran dan bentuk yang berbeda-beda. Pembagian atau perbandingan tersebut menjadi jelas berdiri atau duduk/ bersila, asesoris pada mahkota, subang, gelang, uncal, sabuk, dan kain yang dikenakan. Sementara itu, ikonometri memuat tentang ukuran besar atau kecilnya sebuah arca berdasarkan pada tokoh yang diarcakan. Arca dewadewa utama, berukuran lebih panjang

Tabel 1. Cara pengukuran yang digunakan para seniman dalam merancang pembuatan arca.

\begin{tabular}{|c|c|c|}
\hline KATEGORI & UKURAN & KELOMPOK DEWA MAHLUK \\
\hline uttamadaśatala & 124 ańgula & Visņu, Brahma, dan Siva \\
\hline madhyama daśatala & 120 ańgula & Sri, Bhumi, Uma, dan Saraswati \\
\hline adhamadaśatala & 116 ańgula & $\begin{array}{c}\text { dewa-dewa lokapala, 12 dewa aditya, 11 dewa } \\
\text { rudra, 8 dewa (Vasu, Aswin, Bhrgu, } \\
\text { Markandeya, Garuda, Sēsa, Durga, Karttikeya) } \\
\text { serta 7 Rsi }\end{array}$ \\
\hline navadaśatala & 114 ańgula & para Kubera dan Navagraha \\
\hline uttamanavatala & 112 ańgula & Yaksa lainnya, Daitya, Gandarva \\
\hline satrya ańgula navatala & 111 ańgula & manusia yang disamakan dengan dewa \\
\hline navatala & 106 ańgula & Raksasa, Indra, Asura \\
\hline astatala & 96 ańgula & manusia biasa \\
\hline
\end{tabular}

Sumber: Acharya tt., 607-609

utamanya untuk menentukan, bagian kepala, bagian badan dan kaki, masingmasing memiliki ukuran, supaya arca tersebut kelihatan proporsional dan indah jika dilihat. Dalam pembuatan arca dewa-dewa Hindu-Budha ada ketentuan yang dimuat dalam kitab çilpaçastra. Membuat sebuah arca dewa ada dua hal yang harus diperhatikan, yaitu dari sisi ikonologi, Ikonologi sebuah ilmu yang secara khusus mempelajari seluk-beluk icon atau objek yang digunakan dalam ritual agama Hindu dan Budha. Objek ini biasanya berupa arca sebagai perwujudan sosok dewa yang dipuja. Pembuatan arca dewa sebagai objek ritual mempunyai persyaratan yang ketat, baik dalam hal penggambarannya maupun dari segi ukuran atau metriknya. Secara khusus, seluk-beluk penggambaran arca dewa dipelajari melalui sebuah studi yang disebut ikonografi, sedangkan seluk-beluk metrik arca dipelajari melalui studi ikonometri. Dalam konteks tersebut ikonografi, memuat ketentuan tentang asesoris dan perlengkapan sebuah arca, karena tiaptiap komponen tersebut mengandung nilai-nilai simbolis yang menjadi salah satu identitas seorang tokoh. Komponen penting tersebut diantaranya, seperti jumlah dan sikap tangan, kaki posisi arca dibandingkan dengan ukuran dewa yang berada di bawahnya, manusia dan raksasa. Selain itu juga ditentukan pembagian secara proporsional antara bagian kepala, bagian badan dan kaki.

Seorang seniman yang ditugasi untuk membuat arca dewa harus mengikuti ketentuan-ketentuan yang berlaku dan termuat dalam çilpaçastra, yang terdiri atas:

a. Rûpabheda, yaitu perbedaan rupa dan bentuk arca

b. Pramanam, yaitu ukuran arca harus tepat

c. sadrçyam, arca harus digambarkan sesuai dengan bentuk yang sesungguhnya yang dapat dilihat (diketahui) dengan jalan meditasi atau yoga

d. Varnakibhangam, permainan dan persesuaian warna

e. Bhawa, permainan perasaan

f. Lavanya, keindahan yang ditimbulkan dari hasil ciptaannya

Dalam ketentuan ikonometri dapat dilihat ukuran metrik arca yang berbeda antara dewa utama (Brahma Wisnu dan Siwa) dengan para dewa atau dewi pada 'tingkat' di bawahnya (Dewi Sri dan Tara) yang derajadnya lebih rendah. Dewa utama memiliki ukuran/ angula yang 
lebih tinggi. Berikut dapat dilihat pada tabel di bawah:

Unsur penting selain ikonometri dalam pembuatan arca dewa adalah ikonografi yang mengatur tentang ketentuan dan ciri-ciri kedewaan. Ikonografi berarti "Rincian suatu benda yang menggambarkan tokoh dewa atau seseorang keramat dalam bentuk suatu lukisan, relief, mosaik, arca atau benda lainnya", yang khusus dimaksudkan untuk dipuja atau dalam beberapa hal dihubungkan dengan upacara keagamaan yang berkenaan dengan pemujaan dewa-dewa tertentu (Maulana 1997, 11).

Dalam ikonografi untuk membedakan dewa yang satu dari yang lain dikenal apa yang dalam bahasa sanskerta dinamakan laksana, yang berarti "tanda khusus" yang dipunyai seorang dewa, misalnya benda atau senjata yang dipegang atau diletakkan di dekatnya, vahana (=kendaraan, binatang tunggangan), jenis pakaian tertentu yang dikenakan, ciri tubuh tertentu, yang merupakan tanda pengenal arca dewa tertentu (Sedyawati 1994, 62). Jadi, laksana adalah tanda yang dikaitkan dengan ketentuan -ketentuan keagamaan. Sebagai contoh: Arca Wisnu termasuk dewa utama 124 ańgula (uttamadaśatala) yang bertangan empat, salah satu tangannya memegang senjata cakra. Arca Dewi Sri termasuk dewa kedua 120 ańgula (madhyama daśatala) salah satu tangannya memegang untaian padi sebagai simbul kesuburan dan kehidupan. Arca Ganesha termasuk dalam kelompok ketiga 116 ańgula (adhamadaśatala) berbelalai dan bertaring, dimana salah satu taringnya patah.

Aspek ikonometri dan ikonografi sangat penting sebagai tanda kelengkapan sebuah arca untuk mengetahui siapakah tokoh yang diarcakan dapat diketahui dari atribut yang melengkapinya. Hal tersebut, karena setiap asesoris yang menempel pada arca tersebut mengandung arti atau nilai-nilai simbolis yang melekat atau menjadi satu dengan tokoh tersebut. Sebagai contoh Dewi Sri yang memegang padi tidak mungkin digantikan memegang sebuah senjata cakra milik Dewa Wisnu. Hal itulah merupakan suatu aturan yang tidak dapat diubah oleh pemahat. Oleh karena itu, sang pemahat dituntut untuk membuat arca secara benar dengan mengamati secara detail pada gambar atau melihat langsung arca-arca yang ada candi-candi atau museum-museum.

\section{Membuat Arca Dewa/ Tokoh}

Doelkamid Djajaprana 73 tahun, adalah seorang seniman pahat yang tersohor di Prumpung telah menghasilkan banyak karya-karya arca yang dimanfaatkan untuk kepentingan sakral. Dalam konteks tersebut ia melakukan ritual tertentu sebelum mengerjakan sebuah arca. Tidak ada ketentuan khusus dalam hal ini, tetapi dilakukan dengan cara dan keyakinan mereka masing-masing dengan suatu niat yang baik dan memohon kepada Penguasa Alam Raya. Sebagai orang Jawa, memang harus melakukan 'bersih diri' yaitu dengan melakukan puasa sebelum mulai mengerjakan sebuah arca. Suatu hal yang sangat sulit dalam karya arca adalah wajah tokoh yang dibuat kadang mirip dengan wajah pemahatnya. Namun, dengan melakukan ritual dan pengalamannya hal tersebut dapat diatasi dengan cara melakukan semedi pada malam hari untuk memohon ijin kepada tokoh yang digambarkan supaya hasilnya sesuai dengan wajah tokoh yang dibuatnya. Ritual tersebut dimaksudakan sebagai salah satu syarat untuk menghasilkan karya yang baik dan benar. Pengentahuan tersebut diperoleh dari ayahnya Salim Djajapawira (Almahum) seorang seniman pahat, pasca restorasi Candi Borobudur sekitar tahun 1907 1911 yang dipimpin oleh seorang arkeolog berbangsa Belanda Theodoor Van Erp. Kini, pengetahuan tersebut dilakukan supaya menghasilkan arca berkualitas dan kepuasan batinnya sebagai seorang seniman pahat. Masyarakat sekitar mengistilahkan pembuat arca batu adalah jlagra, berasal dari kata jalagraha (Jawa Kuna)= tukang batu (Wojowasito 1973, 109) merupakan 
sebuah pekerjaan yang harus dilandasi oleh kemauan, kreatifitas dan imajinasi seni yang kuat, karena harus menguasai dan memahami filosofi-filosofi tokoh maupun asesoris kelengkapan arca yang mengandung nilai-nilai dan makna simbolis.

Berdasarkan pengalaman para pemahat, membuat sebuah arca bagian yang paling sulit dikerjakan pada bagian kepala dan wajah, terutama membuat bagian wajah Sang Budha yang memiliki ciri khas dengan bibir tersenyum dan memberikan kesan damai bagi yang melihatnya. Oleh karena itu, diperlukan ketelitian, kesabaran dan kehati-hatian jangan sampai salah apalagi patah (gempil). Sementara itu membuat wajah dewa-dewa/ tokoh yang lain dengan karakter yang dipahatkan, misalnya tersenyum, ketawa, murka dan muram. Bagi pemahat yang berpengalaman, untuk menghindari kesalahan dalam pentatahan dan menghasilkan arca yang sempurna, sebagai seorang Jawa, sebelumnya melakukan ritual, antara lain:

a. Melakukan puasa, waktu dan lamanya dapat ditentukan sendiri, apakah akan dilakukan selama tiga hari atau tujuh hari, tergantung dari kesiapan mental-spiritual dan 'berat atau ringannya' tokoh yang akan dibuatnya. Kemudian pada hari yang telah ditentukan, para tetangga dekat diundang untuk ikut mendoakan dengan seperangkat sesajian berupa sego megono. Doa yang dipimpin langsung oleh pemahatnya, dimaksudkan untuk memohon pada Yang Kuasa, agar dapat menyelesaikan pekerjaan dengan lancar dan selamat.

b. Kemudian setelah doa selesai, terlebih dahulu bahan yang akan ditatah dipegang, dielus-elus dengan penuh perasaan dan di 'sapa' secara batin. Sapaan tersebut dilakukan, agar antara arca yang dikerjakan, tokoh yang digambarkan dan pemahatnya terdapat hubungan batin/ emosional yang kuat.

Keesokan harinya, setelah semua peralatan disiapkan, mulailah melakukan pengukuran arca atau tokoh yang akan dibuat dengan komposisi/ perbandingan, sebagai berikut: Sebagai contoh untuk arca Loro Jonggrang dengan perbandingan; $1: 6: 2$. Angka 1; Pengertiannya adalah satu kilan (jengkal) untuk bagian kepala. Angka 6 (enam): pengertiannya adalah 6 kilan untuk bagian badan dan kaki. Angka 2 (dua): Dua kilan untuk ukuran lebar arca. Ukuran-ukuran tersebut merupakan gambaran yang umumnya digunakan oleh para seniman pahat. Tetapi, dalam prakteknya masih banyak hal yang perlu disesuaikan dan dicermati, utamanya dalam perbandingan tersebut masih dapat dirinci, sebagai berikut:

a. Kepala, dibagi dalam tiga bagian yaitu untuk bagian atas, tengah dan bawah.

b. Bagian badan, dirinci menjadi dua bagian. Dua kilan bagian badan mulai dari bahu sampai dengan bagian pinggul. Sedangkan dari bagian pinggul sampai ke telapak kaki dengan ukuran empat kilan.

Semua langkah tersebut dilakukan agar arca/ arca yang dihasilkan bentuk anatomi tubuhnya kelihatan proporsional, serta indah dipandang mata. Setelah bagian demi bagian tersebut selesai, maka pada tatahan akhir dilengkapi dengan bermacam asesoris sebagai

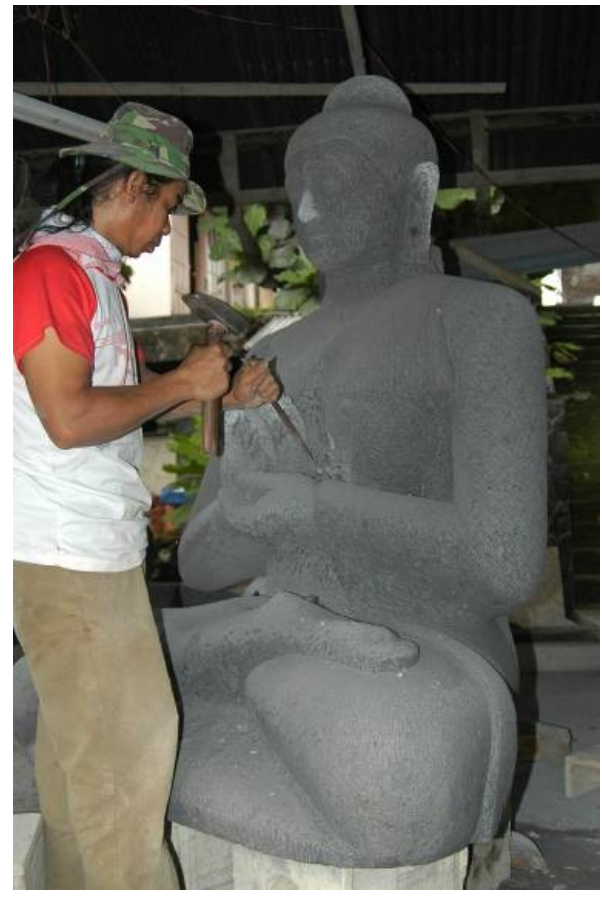

Foto 1. Seorang seniman, sedang memahat detail patung Budha Foto: Balar Yogyakarta 
tanda atau ciri-ciri identitas tokoh yang dibuatnya. Asesoris yang melekat pada tokoh tertentu harus mengikuti ketentuan yang berlaku, karena merupakan tanda atau ciri khas seorang tokoh, sehingga dapat dikenali, siapa tokoh/ dewa tersebut. Beberapa asesoris tersebut seperti bentuk-bentuk senjata, florafauna tertentu yang dipegang oleh sang tokoh, mahkota, subang, kalung, kelat bahu, gelang, sabuk, uncal, badong, celana serta kain yang dikenakan. Selain berfungsi sebagai identitas seorang tokoh/ dewa, asesoris juga berfungsi untuk menambah keindahan sebuah arca dan dapat menutupi kesalahankesalahan yang mungkin dilakukan tanpa disengaja.

Menurut pengakuan para pemahat, sebuah arca akan nampak sempurna dan kelihatan seolah-olah menjadi 'hidup' kalau sudah berumur ratusan tahun, hal tersebut karena bahan batu andesit hasil tambang masih mengeluarkan gas, tetapi mudah ditatah karena belum keras dan tidak mudah patah. Proses pengeluaran gas dari dalam batu tersebut sangat lama, sehingga batu tersebut tidak dapat menyerap dan memantulkan cahaya yang ada di sekitarnya. Setelah gas di dalam batu habis (menguap), maka mulailah batu tersebut menyerap debu dan partikel-partikel kecil lainnya menempel di lapisan luar dan poriporinya tertutup rapat. Akibat proses yang berjalan ratusan tahun tersebut, mengakibatkan permukaan batu akan memantulkan cahaya/ sinar sekitarnya, sehingga arca tersebut kelihatan 'hidup' dan berwibawa menyatu dengan lingkungannya.

\section{KESIMPULAN}

Hasil kajian pembuatan arca di Prumpung telah memberikan sumbangan penting bagi pengetahuan, khususnya etnoarkeologi untuk mencari jawab bagaimana cara pembuaan arca dewa-dewa yang melengkapi sebuah bangunan suci candi, Oleh karena itu, sesua dengan permasalahan tersebut di depan, maka dapat disimpulkan, sebagai berikut: a. Cara pembuatan arca yang diawali dengan mencari sumber bahan batu yang berkualitas, ditinjau dari segi kekompakan porositas batu, warna yang merata dan tidak retak/ pecah. Batu berkualitas baik biasanya diperoleh dengan cara menambang.

b. Peralatan yang digunakan merupakan bahan yang dipesan dari para pande besi atau dibuat sendiri dari bahan baja pilihan. Alat-alat tersebut secara khusus dari bahan terpilih seperti baja dengan kekerasan tertentu melalui proses penyepuhan. Alat yang digunakan terdiri dari: penyecel pencuplik, paju, tatah dan pukul. Selain itu masih banyak peralatan pembantu, seperti, ububan, jambangan air, sabut kelapa, dan kapur tulis/ arang.

c. Arca merupakan komponen penting dalam sebuah bangunan candi. Dibuat oleh para seniman pahat yang profesional, karena untuk membuat sebuah arca (dewa-dewa) diperlukan syarat khusus dengan perilaku ritual. Hal itu dimaksudkan, supaya arca benar-benar kelihatan indah, harus mengacu pada ketentuan pembuatan arca yaitu pada aspek ikonografi dan ikonometri.

\section{UCAPAN TERIMAKASIH}

Pembuatan arca khususnya arca dewa-dewa sebagai perlengkapan bangunan suci/ candi diperlukan persyaratan teknis dan non-teknis. Dalam memberikan informasinya para informan telah banyak menyita waktu. Oleh karena itu, diucapkan terimakasih, kepada, informan terutama Bapak Doelkamid Djojoprono, yang telah meluangkan waktu dan memberikan pengetahuannya kepada penulis, sehingga dapat mengungkap tentang hal-hal berkaitan dengan cara membuat arca secara jelas dan lengkap. Terimakasih kepada pemerintah daerah setempat yang telah memberikan perhatian dan ijin untuk dilakukan kegiatan penelitian, dan kepada anggota tim yang membantu penelitian ini sejak dari persiapan awal sampai akhir penelitian. 
Daru Tjahjono, Baskoro. 2007. Candi Losari, Sebuah Candi di Kawasan Borobudur. Yogyakarta: Kerjasama Yayasan Tahija dengan Balai Arkeologi Yogyakarta.

Ensiklopedia Indonesia.1980. Ensiklopedia Indonesia. Jakarta: van Hoeve, PN. Buku Ichtiar.

Hernaningsih. 1990. Teknik Pembuatan Arca Batu Desa Sidoarjo, Muntilan. Skripsi. Jurusan Seni Murni, Fakultas Seni Rupa dan Disain. Yogyakarta: Institut Seni Indonesia.

Hole. Frank and Robert F. Heizer. 1973. An Introduction to Prehistoric Archaeology 3nd Editions. New York: Holt, Rinehart and Winston Inc.

Maulana, Ratnaesih. 1997. "Kaitan Teknik, Bahan dan Media Arca Dalam Gaya Seni Arca Masa Hindu-Budha di Indonesia" dalam Cakrawala Arkeologi. Depok: Universitas Indonesia.

Sedyawati, Edi. 1994. Pengarcaan Ganesa Masa Kadiri dan Singasari, Sebuah Tinjauan Kesenian. Lembaga IImu Pengetahuan Indonesia bekerjasama dengan Ecole Francaise D'extreme-Orient.

Watson. Patty Jo, Steven A. Le Blanc, dan Charles L. Redman. 1971. Explanation in Archaeology: An Explicity Scientific Approaach. New York: Colombia University Press.

Wojowasito, Soewojo. 1973. Kamus Kawi (Jawa Kuna)-Indonesia. Malang: Jurusan Bahasa dan Sastra Indonesia FKSS. IKIP.

google.map it imagery (c) 2013 terrametrics. 
